\title{
Novel investigational vascular endothelial growth factor (VEGF) receptor antagonists for psoriasis
}

DOI:

10.1517/13543784.2016.1153064

\section{Document Version}

Accepted author manuscript

Link to publication record in Manchester Research Explorer

\section{Citation for published version (APA):}

Malecic, N., \& Young, H. S. (2016). Novel investigational vascular endothelial growth factor (VEGF) receptor antagonists for psoriasis. Expert Opinion on Investigational Drugs, 25(4), 455-462.

https://doi.org/10.1517/13543784.2016.1153064

\section{Published in:}

Expert Opinion on Investigational Drugs

\section{Citing this paper}

Please note that where the full-text provided on Manchester Research Explorer is the Author Accepted Manuscript or Proof version this may differ from the final Published version. If citing, it is advised that you check and use the publisher's definitive version.

\section{General rights}

Copyright and moral rights for the publications made accessible in the Research Explorer are retained by the authors and/or other copyright owners and it is a condition of accessing publications that users recognise and abide by the legal requirements associated with these rights.

\section{Takedown policy}

If you believe that this document breaches copyright please refer to the University of Manchester's Takedown Procedures [http://man.ac.uk/04Y6Bo] or contact uml.scholarlycommunications@manchester.ac.uk providing relevant details, so we can investigate your claim.

\section{OPEN ACCESS}




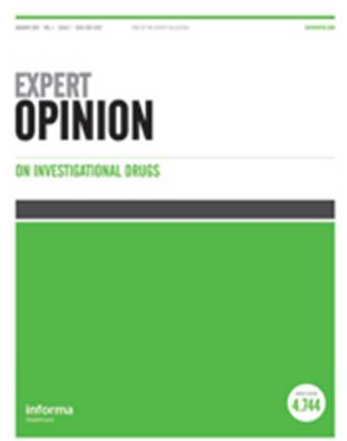

Please download and read the instructions before proceeding to the peer review

\section{Novel investigational VEGF receptor antagonists for psoriasis}

\begin{tabular}{|r|l|}
\hline Journal: & Expert Opinion On Investigational Drugs \\
\hline Manuscript ID & EOID-2015-0184.R1 \\
\hline Manuscript Type: & Review \\
\hline Keywords: & $\begin{array}{l}\text { Psoriasis, Treatment, Angiogenesis, Vascular endothelial growth factor, } \\
\text { VEGF }\end{array}$ \\
\hline
\end{tabular}

SCHOLARONE ${ }^{m}$

Manuscripts 


\title{
Novel investigational Vascular Endothelial Growth Factor (VEGF)
}

receptor antagonists for psoriasis

\begin{abstract}
Introduction: Affecting 1 million people in the UK, psoriasis is a commonly diagnosed inflammatory disease arising from autoimmune processes that are triggered by environmental factors in genetically susceptible individuals. The pathophysiology of psoriasis has been widely studied and there is evidence that angiogenesis is a key component.
\end{abstract}

Areas covered: In this review the role of vascular endothelial growth factor-A (VEGF), as a key angiogenic mediator in psoriasis pathogenesis is discussed. VEGF is found in higher levels in plaques, normal skin and plasma of patients with psoriasis. The level of VEGF also fluctuates in accordance with disease activity and in response to conventional treatments. There are several VEGF inhibitors currently licenced for use; primarily in the fields of oncology and there are case reports of patients being treated with these therapies for metastatic cancer who have demonstrated significant improvement in their 
psoriasis. VEGF inhibitory agents have suggested promising utility for the treatment of psoriasis following animal studies.

Expert opinion: VEGF may represent a novel treatment target in psoriasis. However, VEGF inhibitors can cause significant side effects such as hypertension and left ventricular dysfunction. The risks of treatment must be carefully evaluated before VEGF inhibitors are trialled or advocated for psoriasis.

\section{INTRODUCTION}

In the UK, 1 million people are affected by psoriasis.(1) The visible nature of the disease and its relapsing-remitting nature can have a profound effect on the psychological well-being of individuals with psoriasis.(2) Psoriatic arthritis and metabolic syndrome are systemic manifestations of the disease.(3)

Psoriasis vulgaris, chronic plaque psoriasis, is the most commonly diagnosed psoriasis subtype. The cardinal features of the disease include - thickened, 
erythematous, scaly plaques which are well circumscribed on the surrounding normal-looking skin. (4) Plaques of psoriasis are histologically characterised by: 1) infiltration of inflammatory cells into the dermis and epidermis; 2) hyperplasia of the epidermis; 3) altered differentiation of keratinocytes and; 4) angiogenesis in the dermis. $(5,6)$

Both environmental and genetic factors play a role in the aetiology of psoriasis. Psoriasis pathophysiology has an autoimmune basis and T helper-1 cells and T helper-17 cells have been highlighted as key components of the condition. In addition, endothelial cells, monocytes, neutrophils, dendritic cells and keratinocytes are involved in the inflammatory response in psoriasis.(7) Angiogenesis has also been recognised as a key, early feature of psoriasis.

It is well established that VEGF is an important mediator of pathological and physiological angiogenesis. VEGF stimulates mitosis in endothelial cells and increases vascular permeability and also contributes to chemotaxis and activation of monocytes.(8) VEGF is synthesised in the keratinocytes of the 
epidermis and augmented levels are found in both the plasma and psoriatic plaques in psoriasis sufferers. The level of circulating VEGF corresponds with the level of disease activity.(7-9)

Current treatments for psoriasis such as cyclosporine(10), infliximab(11), psoralen ultraviolet A (PUVA) phototherapy(12), fumaric acid esters(13, 14) and acitretin(9) have diminished plasma levels of VEGF in patients with psoriasis. Animal studies have shown that anti-VEGF therapy can inhibit angiogenesis and can rectify immunological and epidermal changes in psoriasis.(15) However, VEGF receptor antagonists are not currently licensed for the treatment of psoriasis; although they are used for the treatment of metastatic malignancy. $(16,17)$

This article will review the current literature on VEGF receptor antagonists and highlight further research findings since the time of our last publication in this area. 


\section{VEGF}

VEGF is a key angiogenic cytokine in both physiological and pathological contexts. $(8,18,19)$ It is now understood that VEGF belongs to a family of closely related vascular growth factors that have a unique role in controlling growth and differentiation of multiple anatomic components of the vascular system. In addition to VEGF (also known as VEGF-A) the VEGF-family also includes placental growth factor (PIGF), VEGF-B, VEGF-C, VEGF-D and a viral form, VEGF-E.(20) In the remainder of this paper VEGF-A will be referred to as VEGF.

The human VEGF gene has nine possible exons and consequent upon alternative exon splicing a number of different VEGF isoforms, of varying amino acid length, can be generated.(21) Commonly occurring VEGF isoforms include - VEGF121, VEGF165, VEGF189, VEGF206.(22) VEGF specifically stimulates mitosis in endothelial cells, increases vascular 
permeability, and contributes to chemotaxis and activation of monocytes. (19,

$21,23)$

VEGF ligands selectively bind to VEGF receptors (VEGFR)s which are tyrosine kinases (TK)s.(24) VEGF itself binds with a high level of affinity to two receptor TKs, VEGFR-1 and VEGFR-2, both of which are found on the cell surface membrane of endothelial and bone marrow derived cells.(25)

\section{VEGF IN PSORIASIS}

VEGF is synthesised in the keratinocytes of the epidermis and increased levels are found in both the normal and affected skin of psoriasis sufferers and the quantity of circulating VEGF is associated with the degree of psoriasis activity.(26) In addition, elevated plasma levels of VEGF are associated with early onset psoriasis (onset before the age of 40 years) and psoriatic arthritis.(27) 
Polymorphisms of the VEGF gene have been found to be associated with psoriasis which occurs before the age of 40 years. $(28,29)$ The PSORS1 genetic locus has been implicated in the inheritance of psoriasis and is located near to the VEGF gene on chromosome 6p21. Despite this, linkage disequilibrium has not been demonstrated between the VEGF gene and the PSORS 1 locus. (30)

Some systemic therapies which are currently used / licenced for the treatment of psoriasis treatment have been associated with a reduction in plasma levels of VEGF in patients with psoriasis.(31) A meta-analysis of 13 studies concluded that significantly increased serum levels of VEGF were found in patients with psoriasis in comparison to healthy control subjects prior to initiation of treatment with narrow band UVB. Furthermore, there was a documented significant overall decrease in VEGF levels in psoriasis sufferers after successful treatment. (32) 
In contrast, other groups have reported that successful treatment of psoriasis with narrow-band (NB)-UVB and retinoid (re)-PUVA has been associated with increased plasma levels of VEGF.(33) Possible mechanisms, underlying these seemingly contradictory findings, could include increased epidermal proliferation following UVB exposure and individual variability in the response of patients to retinoid therapy.(4) It is possible that retinoid treatment causes a rebound increase in VEGF levels due to increased production of VEGF by mononuclear cells in some patients.(34) In addition, in vivo studies have demonstrated that UV light can provoke epidermal hyperplasia and that exposure to UVB can result in upregulation of VEGF in the skin.(35) We have previously speculated that a similar process may occur in the irradiated skin of many patients but that the balance remains in favour of a beneficial therapeutic effect via other mechanisms. (4)

Xia et al. described the development of psoriasiform skin lesions in transgenic VEGF mice. Clinically, histologically and immunologically, the skin lesions demonstrated the characteristic features of psoriasis; including the koebner 
phenomenon. Raised levels of VEGF were observed in the epidermis, dermis and plasma of the mice. Administration of a VEGF antagonist lead to clinical resolution of the psoriasis-like lesions and rectified the immunological changes in the skin.(15)

A study on K14-VEGF transgenic mice showed that IBI303, a fully human recombinant TNF- a decoy receptor agent, had both anti-inflammatory and anti-angiogenic effects. TNF- $\alpha$ performs a key function in the stimulation of VEGF expression, and is thus implicated in the process of angiogenesis. It was suggested that the probable benefit of treatment with TNF- $\alpha$ inhibitors to patients with psoriasis was the observed dual inhibition of both angiogenesis and inflammation.(36)

A study into the effect of honokiol $(\mathrm{HK})$ in psoriasis further highlighted the role of TNF- $\alpha$ in angiogenesis. It was observed that HK had anti-inflammatory and anti-angiogenic effects through reduction of the ratio of Th1/Th2 expression in CD4(+) T cells, thereby reducing the level and availability of VEGFR-2. This 
in turn resulted in inhibition of TNF- $\alpha$ induced activation of NF-KB. Mice treated with HK demonstrated morphological and histological improvement in psoriasis-like lesions.(37)

\section{PHARMACEUTICAL VEGF INHIBITION}

Therapies that act specifically upon VEGF are not currently licensed for the treatment of psoriasis. However they are licenced and used for the treatment of other diseases including malignancies and ophthalmic conditions. $(38,39)$

Currently available anti-VEGF agents target VEGF in a variety of ways including:

1) Blockade of the interaction between VEGF and its receptors, for example VEGF receptor antagonists such as aflibercept and pegaptanib.

2) Inhibition of VEGF receptor function. Examples of drugs which have this mechanism of action include: sunitinib, sorafenib, vandetanib, pazopanib. 
3) Direct inhibition and targeting of VEGF by monoclonal antibodies, such as bevacizumab and ranibizumab. (4)

\section{VEGF INHIBITION IN CASES OF PSORIASIS (Table 1)}

\subsection{Tyrosine Kinase Inhibitors}

Tyrosine kinases are a type of human kinase enzyme which function by facilitating phosphorylation of a target protein, such as a transcription factor, which leads to structural alteration and thereby a change in activity in the target protein.(40)

TK inhibitors (TKI)s are small molecules which can travel across the plasma membrane of a cell and influence TK mediated activity within the cell.(41) TKIs can exert their effect on numerous kinase receptors and influence a range of physiological mechanisms including angiogenesis through direct action on VEGFR.(42) 
There are 3 categories of TKIs, which are classified or grouped according to their mechanism of action. Type I TKIs competitively inhibit ATP binding to the activated kinase enzyme. Sunitinib is classified as a Type I TKI. Type II TKIs indirectly compete with ATP by binding to the receptor kinase in its structurally inactive form. Sorafenib is included within this category. Type III TKIs are covalent inhibitors which form a covalent bond between cysteines and specific sites on the kinase. Vandetanib is an example of a type III TKI.(42)(43)

\subsubsection{Sunitinib}

In 2007 sunitinib was granted a licence for the treatment of renal carcinoma and advanced gastrointestinal stromal tumour.(43) The drug acts by inhibiting the TK domain on the VEGFR. Two case reports have been described of patients with pre-existing psoriasis being treated with sunitinib for metastatic renal cell carcinoma. In both cases, the patients noted a marked improvement in their psoriasis which was temporally related to the time of their treatment. 
In the first case, a male patient with metastatic renal cell carcinoma (and a 20-

year history of psoriasis) was randomised to receive interferon alpha (IFN- $\alpha$ )

treatment in a randomised control trail, comparing the efficacy of IFN- $\alpha$ to

sunitinib. His treatment was discontinued after 6 months due to increasing

severity of his psoriasis. IFN- $\alpha$ has been implicated in exacerbation of psoriasis in some patients and it was therefore substituted for sunitinib four weeks later. Introduction of sunitinib was associated with significant clearance of psoriasis. Furthermore, clinical improvement was associated with the timing of subsequent treatment cycles. Significant improvement in psoriasis was observed during each 4 week sunitinib treatment cycle and a decline psoriasis control was observed during the two weeks between treatment cycles. (45)

In the second case, a 60 year old male patient (with a 5-year history of psoriasis) commenced sunitinib treatment, for metastatic renal cell carcinoma. Two weeks after initiation of sunitinib treatment, the patient's psoriasis demonstrated considerable improvement. Similar to the previous case, the 
skin lesions were better during the 4 week cycles of sunitinib treatment and worse during the 2 week interval between treatment cycles.(46) The patient was treated with sunitinib for 3.5 years, and throughout this time there was a sustained and clinically significant improvement in his psoriasis.

Notably both patients with psoriasis tolerated treatment with sunitinib well. Alteration in taste was noted in one patient; and grade II fatigue and stomatitis was documented by the other. (45)(46)

\subsubsection{Sorafenib}

Sorafenib is an oral multikinase inhibitor and acts upon the TK component of the VEGFR. The drug is currently licensed for the treatment of advanced renal cell carcinoma and liver cancer which is not suitable for resection. (47)

A case report describes a 78 year old male patient who had a 56 year history of psoriasis and was treated with sorafenib for metastatic renal cell carcinoma. After 3 weeks of treatment with sorafenib there was marked 
improvement in the patient's psoriasis. In particular there was resolution of a recalcitrant plaque of psoriasis on the posterior mid-thorax after 1-month and after 4-months of sorafenib the patient was entirely clear of psoriasis.

\subsection{Monoclonal Antibody Therapy}

\subsubsection{Bevacizumab}

Bevacizumab is a recombinant, humanised VEGF monoclonal antibody derived from mouse anti-VEGF antibodies.(48) Bevacizumab was initially licensed in the United States as a first line treatment agent for metastatic colon cancer.(49) It is also used more widely as a second line treatment for other oncological conditions and is used off-licence for a variety of ophthalmic conditions, including diabetic retinopathy and wet Age Related Macular Degeneration (AMD).(50)

A 2009 case report documented a 60 year old male patient being treated with bevacizumab for metastatic colon cancer.(51) The patient had a 40 year history of psoriasis that covered $40 \%$ of his body surface area. Forty-five days 
after the initiation of bevacizumab treatment, clinical improvement of the psoriasis lesions was noted and this was maintained on 3 month follow up. Although no side effects were reported specifically in this case report, the most significant side effects of systemically administered bevacizumab are hypertension and proteinuria. $(23,45)$

In 2014, a case report describing a beneficial effect of bevacizumab treatment on both psoriasis and psoriatic arthritis (PsA) was published.(52) In summary, a 65 year old gentleman, with a past medical history of psoriasis for 40 years and psoriatic arthropathy for 30 years, was commenced on treatment with bevacizumab and IFN- $\alpha$ for metastatic renal carcinoma. At the time of presentation, the patient had had active psoriasis for 20 years having an arthritis disease activity score (DAS)28 of 6.8 , with polyarthritis affecting the wrist joints, metocarpophalangeal joints, proximal and distal interphalangeal joints. In addition, he had significant, active psoriasis affecting $50 \%$ of his body surface area (BSA). (52) 
Following treatment with bevacizumab there was considerable improvement in both the psoriatic plaques ( $<1 \%$ BSA affected after 3 months of treatment) and the amount of active synovitis (DAS28 of 2.8 at 24 months).(52) This response suggested that treatment with bevacizumab may counteract the deleterious effect of IFN- $\alpha$ on psoriasis.

However, due to asymptomatic proteinuria, the bevacizumab therapy was changed to first sorafenib and then to sunitinib. Following this change, there was a recurrence of both the psoriasis and the PsA.(53) Due to an increased serum creatinine, sunitinib was discontinued and bevacizumab was reinstated at a lower dose. This treatment was tolerated well with no major side effects and a remission in both the psoriasis and PsA was observed again.(52)

The significant improvement seen with bevacizumab, but not with sunitinib is intriguing. However, it is well recognised that individuals with psoriasis can display variable responses to treatment for the disease. In addition, stresses, such as systemic illness, are known to exacerbate psoriasis. 
Removal of such stressors can be associated with improvement of psoriasis and it may be that response to treatment of the underlying malignancy contributed to the improvement in the skin disease.

\subsection{Safety and Tolerability}

The side effects commonly observed from sorafenib are similar to sunitinib, and include diarrhoea, hand-foot syndrome, alopecia, desquamating skin rash, fatigue and hypertension. Side effects usually manifest early in the treatment and are mild to moderately severe.(47)

There may be a concerning association between TKI treatment and cardiovascular events, including impaired left ventricular function, congestive cardiac failure and hypertension. This association is currently unconfirmed by previous studies and requires further research. Both sunitinib and sorafenib have not been assessed for efficacy and safety in psoriasis management. (5457) 
The most common side effects of bevacizumab treatment include hypertension (36\% of patients) and proteinuria (21-64\% of patients).(58) In patients with cancer there are reports of increased risk of thrombotic events, haemorrhage (including gastrointestinal perforation) and delayed wound healing.(59)

\section{EMERGING EVIDENCE FOR EFFICACY IN PSORIASIS (Table 2)}

\subsection{VEGF receptor blockade}

\subsubsection{Blockade of VEGFR-1 and VEGFR-2 by monoclonal antibodies}

The monoclonal rat antibodies MF-1 and DC101 bind to and inhibit the function of VEGFR-1 and VEGFR-2 respectively. An in vivo study, where MF-1 and DC101 were administered simultaneously by intraperitoneal injection to wild-type mice, demonstrated a marked reduction in skin inflammation that had been experimentally induced in the mice. Further analysis revealed that inflammation, oedema and lymphatic vessel size were significantly diminished in the treated mice when compared with the 
placebo treated group. Single administration of either antibody had no significant influence on the inflammatory skin reaction and single administration of the anti-VEGFR-1 antibody only significantly reduced infiltrating $C D 11 b+$ macrophages. This study suggested that dual administration of MF-1 and DC101 was required to induce resolution of skin inflammation. (60)

\subsubsection{Aflibercept}

Aflibercept is a fusion protein which contains binding domains which mimic human VEGFR-1 and VEGFR-2. It binds to circulating VEGF, VEGF-B and PIGF, having markedly greater affinity than bevacizumab and therefore acts as a decoy receptor.(61) Aflibercept is licenced for the treatment of wet agerelated macular degeneration and is administered by intravitreal injection. One advantage of treatment with aflibercept in comparison to bevacizumab, ranibizumab and pegaptanib is that the therapeutic effect of aflibercept is longer lasting and therefore treatment can be administered to patients less often.(62) Aflibercept could potentially be used for a broad range of 
malignancies, including adenocarcinoma of the lung(63), inoperable malignant melanoma (64) and metastatic colorectal cancer.(65)

Psoriasiform lesions, experimentally induced, on the skin of VEGF-transgenic mice demonstrated marked resolution, both clinically and on histological examination, following administration of aflibercept. Specifically, histological assessment demonstrated normalisation of the rete ridges, and a reduction in parakeratosis and vascular hyperplasia. Immunohistochemical staining demonstrated that CD8+ lymphocyte infiltration in the epidermis was no longer detectable and that markers of abnormal epidermal differentiation and vascular inflammation were significantly reduced.(15)

\subsubsection{Valpha}

Valpha is a chimeric fusion protein that exerts its effects on VEGF by acting as a decoy receptor. It contains the binding domain of VEGFR-1 for VEGF, the binding site of the TNF receptor 2 for TNF- $\alpha$ and the Fc portion of human immunoglobulin G1 (IG1). To date, there have been no studies of Valpha in 
humans. However, in vitro studies have demonstrated that Valpha binds to

TNF- $\alpha$ and VEGF simultaneously and that this leads to reduced activation of cultured lymphatic endothelial cells and diminished migration of cultured vascular endothelial cells.(66)

In an in vivo study, Valpha was administered to VEGF transgenic mice over a 2 week period. The results were promising; showing reduced epidermal hyperplasia, and decreased blood and lymphatic vessel surface area in comparison with control mice that were treated with either etanercept or aflibercept.(66)

\subsection{Impairment of VEGFR function}

\subsubsection{NVP-BAW2881}

Created for the Novaris TKI programme, NVP-BAW2881 targets the TK domain of VEGFR-2.(67) The molecule has shown significant potency, and nanomolar concentrations have been shown to reduce proliferation and migration of endothelial cells and inhibit endothelial tube development.(67) 
NVP-BAW2881 is different from other anti-angiogenic treatments as it can be formulated as both oral and topical preparations. Topical administration of bevacizumab could overcome some of the concerning side effects of orally administered anti-VEGF agents, including haemorrhage and gastro-intestinal perforation.(67)

Oral administration of NVP-BAW2881 demonstrated greater efficacy than topical administration. Trans-genic mice with psoriasis-like lesions were randomised to receive either oral or topical NVP-BAW2881 for a 14 day treatment period. In comparison to control treated mice, both preparations of NVP-BAW2881 effected a significant reduction in cutaneous inflammation and lymph node enlargement. Histologically, the skin lesions demonstrated reduced infiltration of leucocytes; reduced epidermal hyperproliferation and hyperkeratosis and inhibition of angiogenesis as evidenced by a decrease in size and number of blood vessels.(67) 


\section{CONCLUSION}

There is good evidence supporting a role for angiogenesis in the pathogenesis of psoriasis. However, both environmental and genetic factors contribute to the manifestation of psoriasis and the aetiology of the disease is multifactorial. Thus, it seems probable that targeting treatment at angiogenesis alone will not be of benefit to all patients.

Nevertheless, VEGF inhibition appears promising as a useful treatment target in psoriasis. There are a variety of treatment possibilities worthy of further investigation. Of particular clinical interest are the TKI agents, as these could provide an opportunity for topical formulation and administration, thus overcoming safety concerns and increasing cost effectiveness. Decoy receptors such as Valpha that exert their effects on VEGF and TNF- $\alpha$ are also especially promising in the treatment of psoriasis. However, further investigation into the safety profile of these putative therapies needs to be carried out as the side effect profile could be a cause for concern in the psoriasis population. 


\section{EXPERT OPINION}

Treatment efficacy in chronic plaque psoriasis has been observed following treatment with anti-VEGF therapies. This is not surprising given that angiogenesis and VEGF, in particular, are fundamental to the development of psoriasis and the wealth of pre-clinical and in vivo data supporting the potential clinical benefit from such therapy. However, VEGF inhibitors are frequently used in the treatment of ophthalmic conditions and oncology and to date, there have only been a small number of case reports published that have documented treatment benefit in chronic plaque psoriasis. It may be that the clinical improvement of psoriatic plaques in patients receiving treatment for other diseases is not recognised by physicians who are not specialists in dermatology. Or a reflection that current anti-VEGF therapy does not sufficiently downregulate the inflammatory angiogenesis observed in the skin in the majority of patients with psoriasis. Certainly, the data from pre-clinical studies is mostly in animal models and therefore extrapolation of the 
hypothesis that anti-VEGF therapy could represent a useful therapeutic strategy in patients with psoriasis into the real-world setting needs further evaluation.

Inhibition of both VEGFR-1 and VEGFR-2 by dual administration of G6-31 and DC101 or aflibercept therapy has generated promising clinical results in murine studies. $(68,69)$ However, caution must be used when extrapolating these results into the dermatology clinic, as murine models cannot mimic the complexity of interaction between genetic and environmental factors that underlie psoriasis. (70) It may be that pharmaceutical inhibition of VEGF may affect mice, some of which have transgenically upregulated levels of VEGF in the skin, more markedly than human subjects with psoriasis.(69)

Nevertheless, novel antibody treatment originating from phage libraries may facilitate translational research, as cross-species cross-reactivity is a risk with older antibodies such as bevacizumab; due to its production process involving humanisation of a murine protein. Genetically engineered antibodies, 
including the G6 group of antibodies, may be more therapeutically effective agents as they bind with greater affinity to VEGF and more securely to VEGFRs.

It has been well established that psoriasis is associated with a high prevalence of major cardiovascular events; for this reason, VEGF inhibitors pose potentially concerning risks to psoriasis patients, as side effects include hypertension, left ventricular dysfunction and gastrointestinal perforation.

Patient response to anti-VEGF treatment for ophthalmic conditions can be predicted by genetic markers; it be would be of great utility if such markers could be identified in psoriasis as treatment could be more appropriately targeted, leading to improved efficacy and safety profile.(71)

Article highlights.

- VEGF mediated angiogenesis contributes to pathophysiology of psoriasis 
- The amount of VEGF in the plasma and skin fluctuates in line with clinical disease severity and in response to treatment.

- TNF- $\alpha$ upregulates VEGF expression. Experimental agents IBI303 and honikiol have demonstrated the anti-angiogenic effects of TNF $-\alpha$ inhibition.

- Case reports detailing clinical improvement of psoriasis in patients treated with anti-VEGF drugs for cancer have been published.

- Murine studies have demonstrated efficacy of anti-VEGF agents in the treatment of psoriasiform skin lesions.

- MF-1 and DC101 -monoclonal antibodies to VEGFR-1 and VEGFR-2

○ Valpha - a chimeric decoy receptor which targets VEGF and TNF$\alpha$

○ NVP-BAW2881 - a receptor tyrosine kinase that can be administered orally or topically

○ G6-31 - a monoclonal antibody with high binding affinity for mouse and human VEGF

- Despite the evidence base supporting the utility of anti-VEGF therapy for the treatment of psoriasis, further research is required and safety concerns must be addressed before use in dermatological practice.

\section{REFERENCES}

1. Christophers E. Psoriasis--epidemiology and clinical spectrum. Clinical and experimental dermatology. 2001;26(4):314-20.

2. Rapp SR, Feldman SR, Exum ML et al. Psoriasis causes as much disability as other major medical diseases. Journal of the American Academy of Dermatology. 1999;41(3 Pt 1):401-7. 
3. Armstrong AW, Harskamp CT, Armstrong EJ. Psoriasis and metabolic syndrome: a systematic review and meta-analysis of observational studies. Journal of the American Academy of Dermatology. 2013;68(4):654-62.

4. Weidemann AK, Crawshaw AA, Byrne E et al. Vascular endothelial growth factor inhibitors: investigational therapies for the treatment of psoriasis. Clinical, cosmetic and investigational dermatology. 2013;6:233-44.

5. Griffiths CE, Barker JN. Pathogenesis and clinical features of psoriasis. Lancet (London, England). 2007;370(9583):263-71.

6. Barker JN. The pathophysiology of psoriasis. Lancet (London, England). 1991;338(8761):227-30.

7. Lowes MA, Bowcock AM, Krueger JG. Pathogenesis and therapy of psoriasis. Nature. 2007;445(7130):866-73.

8. Detmar M, Brown LF, Claffey KP et al. Overexpression of vascular permeability factor/vascular endothelial growth factor and its receptors in psoriasis. The Journal of experimental medicine. 1994;180(3):1141-6.

* first paper to document raised levels of VEGF and VEGFR in psoriasis

9. Young HS, Summers AM, Bhushan M et al. Single-nucleotide

polymorphisms of vascular endothelial growth factor in psoriasis of early onset. The Journal of investigative dermatology. 2004;122(1):209-15.

** first paper to describe a link between polymorphisms of VEGF gene and psoriasis

10. Hernandez GL, Volpert OV, Iniguez MA et al. Selective inhibition of vascular endothelial growth factor-mediated angiogenesis by cyclosporin A: roles of the nuclear factor of activated $\mathrm{T}$ cells and cyclooxygenase 2 . The Journal of experimental medicine. 2001;193(5):607-20.

11. Markham T, Mullan R, Golden-Mason L et al. Resolution of endothelial activation and down-regulation of Tie2 receptor in psoriatic skin after infliximab therapy. Journal of the American Academy of Dermatology. 2006;54(6):1003-12. 12. Deng $\mathrm{H}, \mathrm{Yan} \mathrm{CL}, \mathrm{Hu} \mathrm{Y}$ et al. Photochemotherapy inhibits angiogenesis and induces apoptosis of endothelial cells in vitro. Photodermatology, photoimmunology \& photomedicine. 2004;20(4):191-9.

13. Meissner M, Doll M, Hrgovic I et al. Suppression of VEGFR2 expression in human endothelial cells by dimethylfumarate treatment: evidence for antiangiogenic action. The Journal of investigative dermatology. 2011;131(6):135664.

14. Garcia-Caballero M, Mari-Beffa M, Medina MA, et al. Dimethylfumarate inhibits angiogenesis in vitro and in vivo: a possible role for its antipsoriatic effect? The Journal of investigative dermatology. 2011;131(6):1347-55.

15. Xia YP, Li B, Hylton D et al. Transgenic delivery of VEGF to mouse skin leads to an inflammatory condition resembling human psoriasis. Blood. 2003;102(1):161-8.

** first paper to describe benefit of VEGF inhibition in psoriasiform skin lesions in mice

16. Kerr DJ. Targeting angiogenesis in cancer: clinical development of bevacizumab. Nature clinical practice Oncology. 2004;1(1):39-43.

17. Kubota Y. Tumor angiogenesis and anti-angiogenic therapy. The Keio journal of medicine. 2012;61(2):47-56. 
18. Folkman J, Shing Y. Angiogenesis. The Journal of biological chemistry. 1992;267(16):10931-4.

* A comprehensive review of the role of angiogenesis in health and disease

19. Ferrara N. Vascular endothelial growth factor: basic science and clinical progress. Endocrine reviews. 2004;25(4):581-611.

* A clear and excellent review of VEGF biology

20. Kiselyov A, Balakin KV, Tkachenko SE. VEGF/VEGFR signalling as a target for inhibiting angiogenesis. Expert opinion on investigational drugs. 2007;16(1):83107.

21. Shinkaruk S, Bayle M, Lain G et al. Vascular endothelial cell growth factor (VEGF), an emerging target for cancer chemotherapy. Current medicinal chemistry Anti-cancer agents. 2003;3(2):95-117.

22. Houck KA, Leung DW, Rowland AM et al. Dual regulation of vascular endothelial growth factor bioavailability by genetic and proteolytic mechanisms. The Journal of biological chemistry. 1992;267(36):26031-7.

23. Clauss M, Gerlach M, Gerlach H et al. Vascular permeability factor: a tumor-derived polypeptide that induces endothelial cell and monocyte procoagulant activity, and promotes monocyte migration. The Journal of experimental medicine. 1990;172(6):1535-45.

24. Ferrara N, Gerber HP, LeCouter J. The biology of VEGF and its receptors. Nature medicine. 2003;9(6):669-76.

25. Takahashi S. Vascular endothelial growth factor (VEGF), VEGF receptors and their inhibitors for antiangiogenic tumor therapy. Biological \& pharmaceutical bulletin. 2011;34(12):1785-8.

26. Bhushan M, McLaughlin B, Weiss JB et al. Levels of endothelial cell stimulating angiogenesis factor and vascular endothelial growth factor are elevated in psoriasis. The British journal of dermatology. 1999;141(6):1054-60. ** A key paper which described the asociation of VEGF in the skin and psoriasis disease severity.

27. Creamer D, Allen M, Jaggar R et al. Mediation of systemic vascular hyperpermeability in severe psoriasis by circulating vascular endothelial growth factor. Archives of dermatology. 2002;138(6):791-6.

28. Brogan IJ, Khan N, Isaac K, et al. Novel polymorphisms in the promoter and 5' UTR regions of the human vascular endothelial growth factor gene. Human immunology. 1999;60(12):1245-9.

29. Watson CJ, Webb NJ, Bottomley MJet al. Identification of polymorphisms within the vascular endothelial growth factor (VEGF) gene: correlation with variation in VEGF protein production. Cytokine. 2000;12(8):1232-5.

30. Young HS, Summers AM, Read IR et al. Interaction between genetic control of vascular endothelial growth factor production and retinoid responsiveness in psoriasis. The Journal of investigative dermatology. 2006;126(2):453-9. 
31. Andrys C, Borska L, Pohl D et al. Angiogenic activity in patients with psoriasis is significantly decreased by Goeckerman's therapy. Archives of dermatological research. 2007;298(10):479-83.

32. Chen H, Li X, Tang R. Effects of Narrow Band Ultraviolet B on Serum Levels of Vascular Endothelial Growth Factor and Interleukin-8 in Patients with Psoriasis. American Journal of Therapeutics. 2015.

33. Akman A, Dicle O, Yilmaz F, et al. Discrepant levels of vascular endothelial growth factor in psoriasis patients treated with PUVA, Re-PUVA and narrowband UVB. Photodermatology, photoimmunology \& photomedicine. 2008;24(3):123-7.

34. Matsumura Y, Ananthaswamy HN. Short-term and long-term cellular and molecular events following UV irradiation of skin: implications for molecular medicine. Expert reviews in molecular medicine. 2002;4(26):1-22.

35. Bielenberg DR, Bucana CD, Sanchez R et al. Molecular regulation of UVBinduced cutaneous angiogenesis. The Journal of investigative dermatology. 1998;111(5):864-72.

36. Liu Y, Yang G, Zhang J et al. Anti-TNF-alpha monoclonal antibody reverses psoriasis through dual inhibition of inflammation and angiogenesis.

International immunopharmacology. 2015;28(1):731-43.

** New investigational agent that has demonstrated efficiacy for treatment of psoriasiform skin lesions in mice

37. Wen J, Wang X, Pei H et al. Anti-psoriatic effects of Honokiol through the inhibition of NF-kappaB and VEGFR-2 in animal model of K14-VEGF transgenic mouse. Journal of pharmacological sciences. 2015;128(3):116-24.

**Novel anti-VEGF agent that was found to histologically and clinically improve psoriasiform skin lesions in mice

38. Korpanty G, Smyth E. Anti-VEGF strategies - from antibodies to tyrosine kinase inhibitors: background and clinical development in human cancer. Current pharmaceutical design. 2012;18(19):2680-701.

39. Veritti D, Sarao V, Lanzetta P. Neovascular age-related macular degeneration. Ophthalmologica Journal international d'ophtalmologie International journal of ophthalmology Zeitschrift fur Augenheilkunde. 2012;227 Suppl 1:11-20.

40. Manning G, Whyte DB, Martinez R et al. The protein kinase complement of the human genome. Science (New York, NY). 2002;298(5600):1912-34.

41. Imai K, Takaoka A. Comparing antibody and small-molecule therapies for cancer. Nature reviews Cancer. 2006;6(9):714-27.

42. Morabito A, Piccirillo MC, Falasconi F et al. Vandetanib (ZD6474), a dual inhibitor of vascular endothelial growth factor receptor (VEGFR) and epidermal growth factor receptor (EGFR) tyrosine kinases: current status and future directions. The oncologist. 2009;14(4):378-90.

43. Rock EP, Goodman V, Jiang JX et al. Food and Drug Administration drug approval summary: Sunitinib malate for the treatment of gastrointestinal stromal tumor and advanced renal cell carcinoma. The oncologist. 2007;12(1):107-13. 
44. Mendel DB, Laird AD, Xin X et al. In vivo antitumor activity of SU11248, a novel tyrosine kinase inhibitor targeting vascular endothelial growth factor and platelet-derived growth factor receptors: determination of a pharmacokinetic/pharmacodynamic relationship. Clinical cancer research : an official journal of the American Association for Cancer Research. 2003;9(1):32737.

45. Narayanan S, Callis-Duffin K, Batten J et al. Improvement of psoriasis during sunitinib therapy for renal cell carcinoma. The American journal of the medical sciences. 2010;339(6):580-1.

* Second case report of improvement of psoriasis during treatment with sunitinib for malignancy

46. Keshtgarpour M, Dudek AZ. SU-011248, a vascular endothelial growth factor receptor-tyrosine kinase inhibitor, controls chronic psoriasis.

Translational research : the journal of laboratory and clinical medicine. 2007;149(3):103-6.

* First case report documenting clinical improvement in psoriasis during treatment with sunitinib for metastatic maligancy

47. Fournier C, Tisman G. Sorafenib-associated remission of psoriasis in hypernephroma: case report. Dermatology online journal. 2010;16(2):17.

48. Presta LG, Chen H, O'Connor SJ, Chisholm V, Meng YG, Krummen L, et al. Humanization of an anti-vascular endothelial growth factor monoclonal antibody for the therapy of solid tumors and other disorders. Cancer research. 1997;57(20):4593-9.

* Case report of a patient who demonstarted improvement in psoriasis when treated with a VEGF anatagonist for malignancy

49. Cohen MH, Gootenberg J, Keegan P et al. FDA drug approval summary: bevacizumab plus FOLFOX4 as second-line treatment of colorectal cancer. The oncologist. 2007;12(3):356-61.

50. Saeed MU, Gkaragkani E, Ali K. Emerging roles for antiangiogenesis factors in management of ocular disease. Clinical ophthalmology (Auckland, NZ). 2013;6:533-43.

51. Akman A, Yilmaz E, Mutlu $\mathrm{H}$ et al. Complete remission of psoriasis following bevacizumab therapy for colon cancer. Clinical and experimental dermatology. 2009;34(5):e202-4.

** This case report describes the improvement in psoriasis following treatment with bevacizumab for maliganancy

52. Datta-Mitra A, Riar NK, Raychaudhuri SP. Remission of Psoriasis and Psoriatic Arthritis During Bevacizumab Therapy for Renal Cell Cancer. Indian Journal of Dermatology. 2014;59(6):632. 
** Most recent case report of improvement in psoriasis during bevacizumab treatment for malignancy

53. Summers J, Cohen MH, Keegan P et al. FDA drug approval summary: bevacizumab plus interferon for advanced renal cell carcinoma. The oncologist. 2010;15(1):104-11.

54. Khakoo AY, Kassiotis CM, Tannir N et al. Heart failure associated with sunitinib malate: a multitargeted receptor tyrosine kinase inhibitor. Cancer. 2008;112(11):2500-8.

55. Di Lorenzo G, Autorino R, Bruni G et al. Cardiovascular toxicity following sunitinib therapy in metastatic renal cell carcinoma: a multicenter analysis. Annals of oncology : official journal of the European Society for Medical Oncology / ESMO. 2009;20(9):1535-42.

56. Telli ML, Witteles RM, Fisher GA et al. Cardiotoxicity associated with the cancer therapeutic agent sunitinib malate. Annals of oncology : official journal of the European Society for Medical Oncology / ESMO. 2008;19(9):1613-8.

57. Schmidinger M, Zielinski CC, Vogl UM et al. Cardiac toxicity of sunitinib and sorafenib in patients with metastatic renal cell carcinoma. Journal of clinical oncology : official journal of the American Society of Clinical Oncology. 2008;26(32):5204-12.

58. Zhu X, Wu S, Dahut WL et al. Risks of proteinuria and hypertension with bevacizumab, an antibody against vascular endothelial growth factor: systematic review and meta-analysis. American journal of kidney diseases : the official journal of the National Kidney Foundation. 2007;49(2):186-93.

59. van Heeckeren WJ, Sanborn SL, Narayan A et al. Complications from vascular disrupting agents and angiogenesis inhibitors: aberrant control of hemostasis and thrombosis. Current opinion in hematology. 2007;14(5):468-80. 60. Kunstfeld R, Hirakawa S, Hong YK, Schacht V et al. Induction of cutaneous delayed-type hypersensitivity reactions in VEGF-A transgenic mice results in chronic skin inflammation associated with persistent lymphatic hyperplasia. Blood. 2004;104(4):1048-57.

* This paper describes the role of VEGF in chronic inflammatory skin disease

61. Holash J, Davis S, Papadopoulos N et al. VEGF-Trap: a VEGF blocker with potent antitumor effects. Proceedings of the National Academy of Sciences of the United States of America. 2002;99(17):11393-8.

62. Stewart MW, Grippon S, Kirkpatrick P. Aflibercept. Nature reviews Drug discovery. 2012;11(4):269-70.

63. Aggarwal C, Somaiah N, Simon G. Antiangiogenic agents in the management of non-small cell lung cancer: where do we stand now and where are we headed? Cancer biology \& therapy. 2012;13(5):247-63.

64. Tarhini AA, Frankel P, Margolin KA et al. Aflibercept (VEGF Trap) in inoperable stage III or stage iv melanoma of cutaneous or uveal origin. Clinical cancer research : an official journal of the American Association for Cancer Research. 2011;17(20):6574-81.

65. Wang TF, Lockhart AC. Aflibercept in the treatment of metastatic colorectal cancer. Clinical Medicine Insights Oncology. 2012;6:19-30. 
66. Jung K, Lee D, Lim HS et al. Double anti-angiogenic and anti-inflammatory protein Valpha targeting VEGF-A and TNF-alpha in retinopathy and psoriasis. The Journal of biological chemistry. 2011;286(16):14410-8.

**A promising agent for the treatment of psoriasis

67. Halin C, Fahrngruber H, Meingassner JG et al. Inhibition of chronic and acute skin inflammation by treatment with a vascular endothelial growth factor receptor tyrosine kinase inhibitor. The American journal of pathology.

2008;173(1):265-77.

** A VEGF antagonist that can be effectively administered orally or topically to treat psoriasiform skin lesions in mice

68. Witte L, Hicklin DJ, Zhu Z et al. Monoclonal antibodies targeting the VEGF receptor-2 (Flk1/KDR) as an anti-angiogenic therapeutic strategy. Cancer metastasis reviews. 1998;17(2):155-61.

69. Schonthaler HB, Huggenberger R, Wculek SK et al. Systemic anti-VEGF treatment strongly reduces skin inflammation in a mouse model of psoriasis.

Proceedings of the National Academy of Sciences of the United States of America. 2009;106(50):21264-9.

70. Zenz R, Eferl R, Kenner L et al. Psoriasis-like skin disease and arthritis caused by inducible epidermal deletion of Jun proteins. Nature.

2005;437(7057):369-75.

71. Agosta E, Lazzeri S, Orlandi P et al. Pharmacogenetics of antiangiogenic and antineovascular therapies of age-related macular degeneration. Pharmacogenomics. 2012;13(9):1037-53. 
Table 1. Licensed vascular endothelial growth factor inhibitors reported to affect coexisting psoriasis during treatment of malignancy

\begin{tabular}{|l|l|l|l|l|l|l|l|}
\hline Year & Author & Drug & $\begin{array}{l}\text { Mechanism } \\
\text { of action }\end{array}$ & $\begin{array}{l}\text { Indication } \\
\text { for } \\
\text { treatment }\end{array}$ & $\begin{array}{l}\text { Preceding } \\
\text { duration of } \\
\text { psoriasis }\end{array}$ & $\begin{array}{l}\text { Effect of } \\
\text { treatment on } \\
\text { coexisting } \\
\text { psoriasis }\end{array}$ & Duration of effect \\
\hline 2007 & $\begin{array}{l}\text { Keshtgapour } \\
\text { et al } 46\end{array}$ & $\begin{array}{l}\text { Sunitinib } \\
\text { (SU-011248) }\end{array}$ & $\begin{array}{l}\text { Receptor } \\
\text { tyrosine } \\
\text { kinase } \\
\text { inhibitor }\end{array}$ & $\begin{array}{l}\text { Metastatic } \\
\text { renal cell } \\
\text { carcinoma }\end{array}$ & 20 & $\begin{array}{l}\text { "Virtual } \\
\text { clearance" }\end{array}$ & $\begin{array}{l}\text { Throughout treatment with cyclical } \\
\text { exacerbations }\end{array}$ \\
\hline 2009 & $\begin{array}{l}\text { Akman et al } \\
51\end{array}$ & Bevacizumab & $\begin{array}{l}\text { Anti-VEGF } \\
\text { monocloncal } \\
\text { antiobody }\end{array}$ & $\begin{array}{l}\text { Metastatic } \\
\text { colon } \\
\text { carcinoma }\end{array}$ & 40 & $\begin{array}{l}\text { Reduction in } \\
\text { PASI from } \\
16.8 \text { to 1.4 }\end{array}$ & At least 3 months (duration of \\
follow-up)
\end{tabular}




\begin{tabular}{|l|l|l|l|l|l|l|l|}
\hline 2010 & $\begin{array}{l}\text { Narayanan } \\
\text { et al 45 }\end{array}$ & Sunitinib & $\begin{array}{l}\text { Receptor } \\
\text { tyrosine } \\
\text { kinase } \\
\text { inhibitor }\end{array}$ & $\begin{array}{l}\text { Metastatic } \\
\text { renal cell } \\
\text { carcinoma }\end{array}$ & 5 & $\begin{array}{l}\text { "Significant } \\
\text { improve" }\end{array}$ & $\begin{array}{l}3.5 \text { years; on-going therapy with } \\
\text { cyclic exacerbations }\end{array}$ \\
\hline $\begin{array}{l}\text { Datta-Mitra } \\
\text { et al 52 }\end{array}$ & Bevacizumab & $\begin{array}{l}\text { Anti-VEGF } \\
\text { moncloncal } \\
\text { antibody }\end{array}$ & $\begin{array}{l}\text { Metastatic } \\
\text { renal } \\
\text { carcinoma }\end{array}$ & 40 & $\begin{array}{l}\text { Reduction } \\
\text { from } 50 \% \\
\text { BSA } \\
\text { coverage to } \\
<1 \%\end{array}$ & Throughout treatment \\
coverage
\end{tabular}


Table 2. Preclinical murine studies investigating possible vascular endothelial growth factor inhibitors

\begin{tabular}{|c|c|c|c|c|c|}
\hline Year & Author & Agent & $\begin{array}{l}\text { Route of } \\
\text { administration }\end{array}$ & $\begin{array}{l}\text { Mechanism of } \\
\text { action }\end{array}$ & Principal findings in treated mice \\
\hline 2003 & Xia et al 15 & $\begin{array}{l}\text { VEGF- } \\
\text { Trap }\end{array}$ & $\begin{array}{l}\text { Subcutaneous } \\
\text { injection }\end{array}$ & $\begin{array}{l}\text { Fusion protein } \\
\text { (decoy } \\
\text { receptor) }\end{array}$ & $\begin{array}{l}\text { Improved clinical appearance, normalisation of clinical } \\
\text { features, including reduction in parakeratosis, vascularity, } \\
\text { epidermal markers }\end{array}$ \\
\hline 2004 & $\begin{array}{l}\text { Kunsfeld et } \\
\text { al } 60\end{array}$ & $\begin{array}{l}\text { MF-I and } \\
\text { DC } 101\end{array}$ & $\begin{array}{l}\text { Intraperitoneal } \\
\text { injection }\end{array}$ & $\begin{array}{l}\text { Rat anti- } \\
\text { VEGFR-1 } \\
\text { mAb and anti } \\
\text { VEGFR-2 } \\
\text { mAb }\end{array}$ & $\begin{array}{l}\text { Decreased skin inflammation, oedema and lymphatic vessel } \\
\text { enlargement }\end{array}$ \\
\hline 2008 & $\begin{array}{l}\text { Halin et al } \\
67\end{array}$ & $\begin{array}{l}\text { NVP- } \\
\text { BAW2881 }\end{array}$ & Oral or topical & $\begin{array}{l}\text { Receptor } \\
\text { tyrosine } \\
\text { kinase } \\
\text { inhibitor }\end{array}$ & $\begin{array}{l}\text { Both formulations effective oral > topical, improved clinical } \\
\text { appearance, decreased number and size of blood vessels, } \\
\text { normalisation of histological features, including decreased } \\
\text { leucocyte infiltration }\end{array}$ \\
\hline 2009 & $\begin{array}{l}\text { Schonthaler } \\
\text { et al } 69\end{array}$ & G6-31 & Anti-VEGF mAb & $\begin{array}{l}\text { Subcutaneous } \\
\text { injection }\end{array}$ & $\begin{array}{l}\text { Improved clinical appearance, normalisation of histology } \\
\text { features including decreased epidermal thickness, vascularity } \\
\text { and leucocyte infiltration }\end{array}$ \\
\hline
\end{tabular}




\begin{tabular}{|l|l|l|l|l|l|}
\hline 2011 & Jung et al & Valpha & $\begin{array}{l}\text { Chimeric fusion } \\
\text { protein (anti- } \\
\text { TNF and anti- } \\
\text { VEGF decoy } \\
\text { receptor) }\end{array}$ & $\begin{array}{l}\text { Subcutaneous } \\
\text { injection }\end{array}$ & $\begin{array}{l}\text { Decreased epidermal hyperplasia, blood vessel area and } \\
\text { lymphatic area }\end{array}$ \\
\hline 2015 & Wen et al 37 & $\begin{array}{l}\text { Honokiol } \\
\text { (HK) }\end{array}$ & $\begin{array}{l}\text { Reduces } \\
\text { Th1/Th2 } \\
\text { expression in } \\
\text { CD4(+) T cells }\end{array}$ & $\begin{array}{l}\text { Topical } \\
\text { application }\end{array}$ & Clinical and histological improvement of lesions \\
\hline 2015 & Liu et al 36 & IBI303 & $\begin{array}{l}\text { TNF- } \text { a decoy } \\
\text { receptor }\end{array}$ & $\begin{array}{l}\text { Subcutaneous } \\
\text { application }\end{array}$ & Clinical and histological improvement of lesions \\
\hline
\end{tabular}

